\title{
Enhancing the Retention of Lectured-Information for Higher Education Students through Note-Taking Skills
}

\author{
Dr. Anamika Jiwane \\ Senior Lecturer, Department of Architecture and Interior Design, University of Bahrain, KINGDOM OF BAHRAIN \\ Corresponding Author: ajiwane@uob.edu.bh
}

\begin{abstract}
Note-taking is an important skill to be taught to the learners so that it can be used as a tool for them to perceive and retrieve the lectured information; especially during Theory courses dealing with intense information. Keeping this in mind I tailored my study which could examine whether Note-Taking, Note-making and Note-reviewing can improve the retention skills of my learners and whether these retention skills can be later used by them to recall the retainedinformation. I tried to measure these retention skills by using customized retention tests to observe the resulted pattern. The research question that guided my study was "How efficiently the Notes-Taking, Notes-Making and Notes-Reviewing can improve the short term retention of lecture-information for the learners in Higher Education at lower level of academic program (Interior design) with respect to free recall, accuracy and comprehension type of questions ?". This qualitative research uses Primary data collected from 22 students. Harmonious to some of the studies in the past, this study reaffirmed the importance and vital impact of Notes taking and reviewing on the short term retention of received information. In addition a pattern was revealed that Notes making enhances comprehension skills and notes reviewing enhances accuracy skills.
\end{abstract}

Keywords - Note-Reviewing, Note-Making, Note-Taking, Retention Interval (RI) / Span, Information Retention, Short Term, Comprehension Skills, Accuracy Skills

\section{INTRODUCTION}

This Action research is designed to test effectiveness of an intervention i.e. Notes Taking and the impact it has on retention skills of learners. In my case, experimental and control group is used to measure their achievements before and after the intervention. I tried to carry out research in a controlled environment to a possible extent to make sure that, changes observed were due to independent variables, and not due to other causes, as extraneous variables. There were many such unplanned and uncontrolled variables that were related to my study and could influence the results, but, the observations in my study were on account of planned intervention assumption that these might not have been impacted by the extraneous elements. Hence, I can confirm the reasonable chances of high internal validity. The objective of my study does not include the generalizability of the results and findings to another population because of certain limitations as part of the study mentioned at the end.

Generally, traditional experimental studies in educational research are designed to test the effectiveness of an intervention (the independent variable) and the impact it has on the dependent (outcome) variable like stimuli and response relationship and the researchers here like to articulate their predictions about relationships by stating their hypotheses prior to the start of the study. I had also anticipated a positive impact of note taking skills on retention levels of learners and made comparison of before and after intervention. Through Action research, I wanted to examine my own educational practice systematically and carefully using transformative reflection (reflect-planapply-evaluate) on my own-teaching-practice. Passion is integral to doing action research and my identified passion was 'to improve and experiment with teaching-learning strategies and techniques.'

\section{Existing situation in Higher Education}

As a common natural phenomenon, people have tendency to forget. According to Ebbinghan's findings, we can retain only $25 \%$ of information after 2-days; while, some studies show that we forget $90 \%$ of received information after one week (Anon, 2017). It has been almost my regular experience that students do not reply to my questions asked during/after the lecture; their low retention levels and comprehension capabilities contribute to their silence in classroom-discussion and they often address the problem of rapid disappearance of the content of what they listen to during lectures. I consider it as a serious problem. Dale's Cone (Anderson, n.d.) shows that when lecturing is done, learners can remember only $5 \%$ of lectured-information but this can be raised to $90 \%$, if learners are allowed and motivated to involve in using multiple-mental-processes simultaneously. Hayati and Jalilifar (2009) suggest that one way to alleviate the problem is to expose learners to varied post-listening activities and note-taking is one such cognitive-learningstrategy (Hismanoglu,2000). Though, Note-taking during lecture is an important learning-tool in Higher Education (HE), we generally hear many students talking about, 'why 
bother taking notes when we have an access to lecture-notes outside of the classroom?'

\section{Statement of Problem}

Lecture is one of the most commonly used teaching-method and may be the most effective method to convey a large amount of information to a large number of students. We, the Faculty Members therefore, have to be continually challenged to develop techniques that can be used to engage our students and provide them with appropriate experiences that can possibly promote their retention skills for lectured information. Earlier studies like by Kiewra et.al. (1991) show that Notes taking can be one such method that can continually engage students during lectures and make learning more active.

But, in spite of knowing the importance, I and my colleagues generally believed that Note-taking is an obvious and spontaneous skill, and therefore, no need to take special efforts to motivate and teach students to take notes as also mentioned by Friedman (n.d.). We also assumed that students know how to do it and did not realize that note-taking is an intricate process which involves phases of 'acquire, mentally represent, select and understand' that depend upon 'working memory'. This is the major reason stated by Piolat, A. (2004) behind unsuccessful note-taking practices. Though, the body of research on note-taking reveals that taking notes in classroom and reviewing those later, positively impact students' learning (Kiewra et al.,1991), majority of our students studying at Universities are either unaware or do not realize the benefits of note-taking on their effective learning. There are references of studies on Academic Practices in Higher Education by Faculty but unfortunately Note-taking practices and their impacts are not significantly measured in any of those studies. After reviewing a number of studies on Note-taking practices, I admit that a time has come when we as instructors have to realize that NT is not a skill all the learners will come equipped with when they join $\mathrm{HE}$ and we cannot leave it to them to learn by trial and error process (Meer, 2012).Fig.1 shows the generally observed teaching learning scenario in the Departments at Higher Education Institutes, which worked as a trigger for me to start with this Action Research.

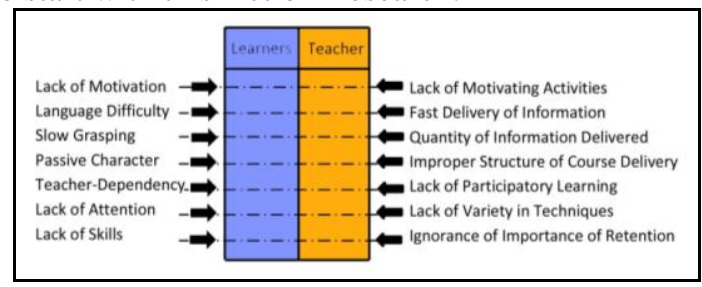

Figure 1. Existing teaching learning scenario at $\mathrm{HE}$ Institutes [source : author]

\section{LITERATURE REVIEW}

According to Dunkel (1988), taking-notes while listening to a lecture is a time honored tradition in academe. Research study by Einstein et al. (1985), reveals that a good reason to take notes is to take every opportunity to record and keep information so you can use it later. Kiewra and Fletcher (1984) suggest that note-taking has the positiveimpact on retention and demonstrated that what is noted is much likely to be remembered than the information not noted. This is also supported by Titsworth (2001). According to Chen (2007) students' performance can be evaluated either by the notes they take or the information they reconstruct with their notes. Kiewra (1989) through his study identifies Note-taking as useful external memory device and has demonstrated its role as a systematic cue and aid for retention. But, ironically, notes-taking-experience is much different for learner in HE today, who has likely grown-up with student-centered learning (Biggs and Tang,2011) and perceives note-taking as less fundamental to their ultimate success, unaware about its foundationbenefits to their learning (Boye,2012).

According to Vanderstoep and Pintrich (2008), Pauk (2001), information that only makes it into sensorymemory is lost unless it is transferred to the workingmemory and eventually a long-term-memory, which is facilitated by the process of taking-notes. Note-taking facilitates both, recall of factual material and the synthesis application of new material and new knowledge, particularly when notes are reviewed prior to exams (Dezure et al. 2002). This emphasizes the act of Notes reviewing. Kiewra et al. (1991), mentions that information from a lecture must be remembered or recorded otherwise it is lost; this is where NT can help which can also facilitate comprehension through internal connections made during the lecture. But only taking notes is not enough, reviewing them later is what yields better academic result, says Kiewra et al. (1991), to highlight Notes reviewing over notes taking. In support his study revealed that students who took no notes or did not study their notes forgot approximately $80 \%$ of the lecture by the end of two weeks (Ref fig 2).

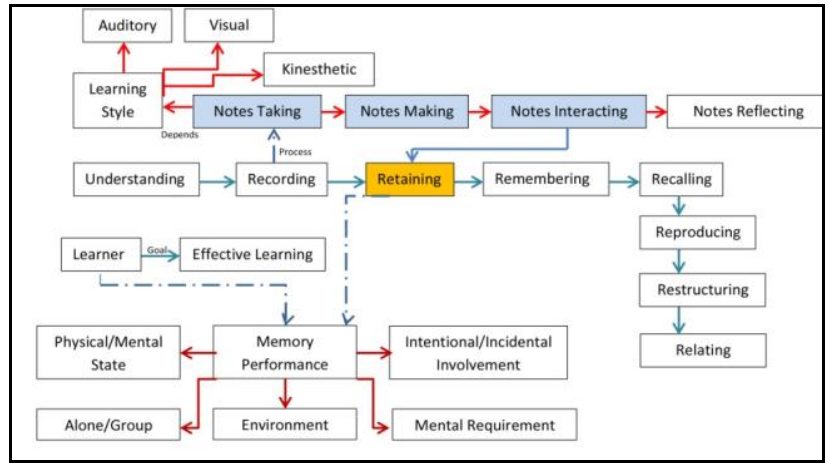

Figure 2. Flow-chart showing effective learning and retention through Notes-taking [source: author] 
Among the teacher-action-researchers, there is a mixed feeling on the role of literature review. Some researchers get easily influenced by the existing research approaches and theories generated by research institutes, think tanks and universities. Whereas some researchers do not have difficulty in designing their studies without a literature review. My experience was that my literature review helped me to focus on my research question, develop my research methodology and data collection methods identifying gaps with previous studies, situating my enquiry within context. I could identify various agreements and disagreements on similar issues. Moreover, it gave me a way to question my findings and make them more meaningful.

\section{The Research}

The main objective of the research is to observe the relationship of notes taking, making and reviewing behavior of learners that enhances their learning and study skills. Their retention levels of lectured-information to be used effectively for free recall, accuracy and comprehensive types of questions (Ref. fig.3).

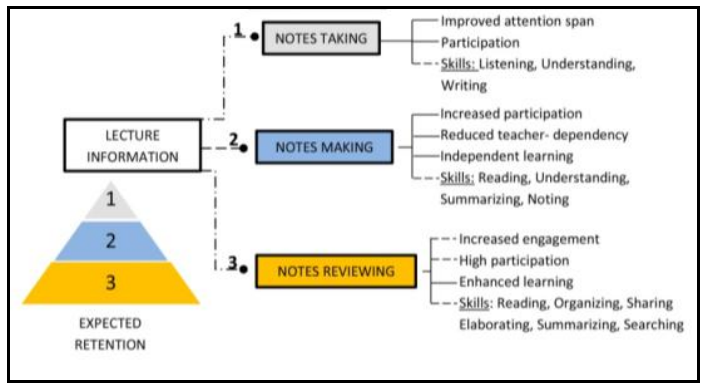

Figure 3. NT, NM and NR as methods of retention [source: author]

My study was focused on the research question "How efficiently the methods of Notes-taking, Notesmaking and Notes-reviewing can improve the shortterm retention of lecture-information for the learners studying at lower levels of academic program in Interior Design?" While framing the question, I made sure that it did not lead to 'yes' and 'no' answer. It was specific but sufficiently open ended to facilitate meaningful exploration and to provide opportunities for deep and rich understanding of teaching and learning in my classroom.

Earlier studies like DeZure et al. (2002); Van Mater and Carter (1975), Kiewra (1991); Di Vesta and Grey (1973); Fisher and Harris (1972); Paper and Mayer (1978) etc. support the finding that Notes-taking and reviewing behavior have a positive impact on retention of lectured information. I had based my AR in support/favor of these findings. During my Action research. I had explained to them that, the tests during the research wouldn't count to their academic grades and their intrinsic motivation was needed to practice these skills.

My study was rooted in various related academic theories like: Schema theory, Transformative Knowledge Theory, Working Memory Theory, Generative theory, Cognitive theory and Constructivism theory. Major support to the research comes from Wittrock's theory (1974), which mentions that sustainable knowledge can be generated only when learners are able to generate relationships and meaning from acquired information. I selected this theory as support to NT. After reading through the different studies, I believe that learner in $\mathrm{HE}$ is not a passive recipient of information and can be transformed into an active participant in the learning process. This can be achieved by allowing the learner to construct meaningful understandings of acquired information during lectures by taking notes. According to Paper and Mayer (1978), Generative Theory states that act of taking notes is a generative technique and results in retention skills. Many mental processes occur simultaneously during the act of NT, hence it is a highly cognitively demanding act (Encoding function of NT) (Kiewra, 1989) and during NT, new-information is added to the earlier knowledge i.e. constructing knowledge (External storage function of NT) (Kiewra, 1989).

\section{METHODOLOGY}

This Action-Research was conducted in 3 cycles: Cycle-1 Notes-Taking (NT), Cycle-2 Notes-Making (NM) and Cycle-3 Notes-Reviewing (NR).The lecturedinformation received and retained through these methods was assessed using tools like Teachers' Observation, Students' Feedback, Retention Tests and Focus Group Discussions (FGD).

Participants: In Interior Design Program, 22 students from the course History and Theory of Interiors-I, consented to participate (voluntarily) in this action-study. Material for assessment during the action research was derived from their course material, and all the cycles were conducted during their lecture hours only. Participants were well informed about the policy that the grades from tests during action study would not be added to their academic performance grades. This was to avoid any influence on the results of action study from any extrinsic motivating factors. Participants belonged to 200 level of the academic program; and the course taken during study was a theoretical course (History) with its intense information taught in English medium. 5 males and 17 females formed the sample group. The participants belonged to different nationalities like Jordan, India, Lebanon, Egypt, Turkey, Pakistan, Sudan etc. and possessed different academic backgrounds. A few have had their earlier school education through English medium but majority did not. I cannot deny 
the possibility that outnumbered females might have influenced the results because females tend to have higher literacy skills (Watson et al., 2010). A focus group was constituted with 8 students having their GPAs ranging from 1.95-3.58/4.00.

Tools, Reliability and Triangulation: During the research, a care was taken to see that none of the unplanned and uncontrolled variables affect the outcomes of study. A strict check was observed on the time span of lecture delivered, the contents( quality, quantity) during lecture, mode of delivery as well as the evaluation methods to be maintained as uniform as possible to avoid any possibility of their influences on the outcomes of study.

Students' Surveys: These were conducted using a questionnaire framed with open and closed ended questions targeting to study note taking behavior of learners. The questionnaire collected both quantitative and qualitative data to analyze the learners' study skills and their perceptions towards improving them. A study by Nisbett and Wilson (1977), shows that people readily answer when they are asked reasons for their behavior, because they draw their answers from social norms related to that behavior and do not do so based on their true introspection. To avoid the risk of influenced opinions, I tried to ask more specific questions to improve internal validity of my tool and avoid perception bias.

Including pre-cycle, 4 types of Feedback survey questionnaires were designed. The very first one at the precycle was designed with 12 questions aiming to receive information from the participants on their existing learning habits, attitudes and awareness on methods and benefits of notes-taking. The questionnaire had both, closed ended as well as open ended questions to allow them to freely express their opinions and acceptance on NT skills. The other questionnaires at cycles 1, 2, and 3 had total 4 questions only with 3 as closed ended and 1 as open ended type aiming to receive opinions from participants on the affectivity of subsequent changes introduced to their learning process to aid their retention of lectured information. Due to the promised anonymity, information received by the participants can be valued as authentic.

Teachers' Observations: Learners were observed in their learning environment especially in-classrooms during the lecture sessions using "Teachers' Observation Technique". A checklist was maintained during all cycles to mark their involvement, participation, motivation and attention during lectures as a result of retention. Photographs are good observation records, but upon the request by some participants and to respect the ethical concern, these were not presented/published during study. "Teachers' observation" is a significant but underutilized assessment technique in academic research. It is sometimes argued that teachers are unable to make appropriate/dependable assessment and judgments from observations of students in natural-settings but, if handled carefully, teachers' observations can provide important evidence for assessment and judgments (Maxwell, 2001). To yield better results, I practiced non-subjective and unbiased behavior to improve affectivity of tool.

Teachers' observation was used as an effective tool during AR. It was performed periodically, by using a checklist during the lecture hours. For this, I prepared a checklist that contained various study behavioral aspects including attention span, preparedness to answer, active participation, raised hands with confidence for participation, facial gestures of satisfaction, note taking activities etc. I also collected samples of students' notes to observe these carefully for quality and quantity aspects. I made marks on their NT modes, graphics used, and any specific method chosen for NT etc. While observing these for assessment, I observed the total words written in relation to the total information units delivered as well as the level of information notes (higher order/ lower order). The checklist had columns with different number-size to note down the quantitative data and empty column to write qualitative data.

Photographs were taken to be used as effective evidential tools; but some participants were not willing to publish their photos during the presentation of research, hence these were used only for study purpose and not for publication.

Retention Tests: Students performance with regards to their retention was assessed using the different sets of retention tests which can be categorized as Information Recall Tests and Information Recognition Tests: free recall test ( memory/ random recall),comprehension test (comparison, conclude, apply etc.) and accuracy test (true/ false, MCQs).These tests were aligned with strategies of acquiring information, strategies of working with information and strategies for confirming learning (assessment) (Biggs and Tangs,2011). I tried to compose the tests in alignment with Bloom's Taxonomy (Ref table 1) and some support from earlier research in the field on note taking for more reliability and validity of this tool.

Table 1

Retention tests and Bloom's taxonomy

\begin{tabular}{|c|c|c|}
\hline Levels & $\begin{array}{l}\text { Verbs and } \\
\text { tests ( based on } \\
\text { Bloom's taxonomy) }\end{array}$ & Tests in my AR \\
\hline Level I & $\begin{array}{l}\text { Knowledge- } \\
\text { recall of information }\end{array}$ & RECALL Test \\
\hline Level II & \begin{tabular}{l}
\multicolumn{2}{c}{ Understandin } \\
$\mathrm{g}$ and being able to \\
interpret \\
$\begin{array}{l}\text { comprehension } \\
\text { application }\end{array}$
\end{tabular} & ACCURACY Test \\
\hline
\end{tabular}




\begin{tabular}{l|l|l|}
\hline \multirow{2}{*}{$\begin{array}{l}\text { The clue of } \\
\text { III }\end{array}$} & $\begin{array}{l}\text { COMPREHENSION } \\
\text { knowledge anderstanding in new } \\
\text { circumstances- } \\
\text { problem solving }\end{array}$ & $\begin{array}{l}\text { Test ( comparison, } \\
\text { justification, analysis) }\end{array}$ \\
\hline
\end{tabular}

During all the cycles of AR, tests were composed to assess the retention of lectured information by the participants. These were categorized based on how learners can utilize retained information to answer - Random questions, accurate questions and analytical questions. Students can remember information to answer these type of questions through NT, NM or NR practices and these can indicate their increasing levels of cognitive capabilities.

Focus Group Discussion: It was arranged twice: during pre-cycle and after cycle-3 to discuss issues related to their learning behavior, retention skills, and perception on NT/NM/NR and to receive their feedback. Flom (n.d.) says that Focus Groups are strong on validity than reliability, but these problems can be lessened by choosing an appropriate representational sample and framing specific questions. In accordance with his suggestion, I chose to form the focus group with participants having different levels of academic abilities (GPAs) to avoid any lopsided opinions.

I guided the Group Discussion by playing the unbiased role of a moderator to let students to have a discussion among themselves; agree and disagree with each other in terms of their beliefs, experiences and practices. The aim to conduct FGD was to explore the meanings of survey findings which could be explained statistically. I developed some key (probing) questions to ensure even participation, and run the session evenly and fairly.

I used more than two methods of data collection during my AR. Regarding 'triangulation of tools' Sabina and Khan (2012), say that multiple methods offer the prospect of enhanced confidence because single method cannot shade adequate light on a phenomenon. Since my study included qualitative and quantitative data, use of multiple methods facilitated my deeper understanding.

Data are everywhere around the educational environment and I considered data collection as a thoughtful and purposeful action. Questions that helped to organize my data collection process were: What data do I need to collect? Why do I need it? Where would I get it from? How would I gather, store, organize, analyze and present the data? How would help me to enquire my research question?

\section{PROCEDURE}

This Action study was conducted in three cycles in addition to a pre-cycle. During the pre-cycle, existing NT behavior of my participants was observed and their retention skills as an outcome of that behavior was assessed using appropriate retention tests. A need was felt to emphasize on notes taking as a compulsory act during lectures to help my students to retain information for short term.

Cycle-1 aimed at teaching linear and non-linear techniques of notes taking. Students were observed on their participation and assessed on their retention levels. Their feedback helped to understand their struggle for taking notes keeping pace of lecture delivery and their language difficulty (English as a second language). Samples of their notes were checked for quality purpose and feedback was given for further improvement. Students faced issues with the formal and strict nature of Cornell Type note taking and hence preferred to use their own methods.

Cycle-2 of Action Research focused on introducing Notes-Making in addition to Notes-Taking. The students were given several tasks, which required them to refer to library books and other learning resources in addition to lectures in class room. Lecture speed was slowed down to help them take down the notes and also a list of hard words for the lecture to be delivered was sent in advance to help their note-structuring. Retention test results revealed satisfactory results in the category of free recall and comprehension type of questions.

Finally, Cycle -3 was conducted with notesreviewing as an effective learning strategy which achieved satisfactory results in the category of free recall and comprehension types of questions to some extent. Cycle 3 was conducted by introducing NR as an effective learning strategy over NT and NM to retain more lectured information. Different notes reviewing techniques were introduced to them including elaboration, reorganization and restructuring of notes. They were asked to review their notes inside and outside of class room. Their notes were collected to observe their methods adopted for notes reviewing.

After every cycle, tests (accuracy, comprehension and free-recall) were conducted to measure the changes and improvements in their retention skills. Students' Feedback as well as feedback from few colleagues (occasionally) was collected after implementing elements of change in every cycle towards the enhancement of retention. Teachers' Observations were used as a tool to note their increased active participation and attention span during the lectures. Their notes were collected time to time to verify the methods used and the completion and quality of information units noted by them.

Students' feedback helped me to link pre-cycle with cycle-1 and cycle-1 with cycle-2. My partner's critique during the POT (Peer Observation of Teaching) process and a Paper Critique by me on a Journal Paper in the field of action Research related to notes taking and retention skills , 
also helped me to introduce required elements of change and observe their impact on action (Ref table 2).

\section{Table 2}

Linking cycles during the action research for improvement

\begin{tabular}{|c|c|c|c|}
\hline $\begin{array}{l}\text { Change of } \\
\text { cycle }\end{array}$ & $\begin{array}{l}\text { Precycle:Cyc } \\
\text { le-1 }\end{array}$ & $\begin{array}{l}\text { Cycle- } \\
\text { 1:Cycle-2 }\end{array}$ & $\begin{array}{l}\text { Cycle-2: } \\
\text { Cycle-3 }\end{array}$ \\
\hline $\begin{array}{l}\text { Existing } \\
\text { situation }\end{array}$ & $\begin{array}{l}\text { Students: } \\
\text { Passive, } \\
\text { teacher- } \\
\text { dependent, } \\
\text { forgetting } \\
\text { quickly, } \\
\text { reluctant } \\
\text { towards } \\
\text { notes-taking } \\
\text { practice } \\
\text { Teachers: } \\
\text { Assuming } \\
\text { students are } \\
\text { learning }\end{array}$ & $\begin{array}{l}\text { Students: } \\
\text { unable } \\
\text { manage to } \\
\text { take notes } \\
\text { keeping pace } \\
\text { with lecture, } \\
\text { need time to } \\
\text { finish the } \\
\text { task of NT } \\
\text { Teacher: } \\
\text { Focus on } \\
\text { lecture } \\
\text { completion }\end{array}$ & $\begin{array}{l}\text { Students: } \\
\text { No } \\
\text { significant } \\
\text { retention of } \\
\text { information } \\
\text { for higher } \\
\text { cognitive } \\
\text { skills, only } \\
\text { NT/NM is } \\
\text { not enough, } \\
\text { because } \\
\text { these help } \\
\text { only } \\
\text { retrieval of } \\
\text { information } \\
\text { from } \\
\text { storage but } \\
\text { cannot } \\
\text { generate } \\
\text { knowledge; } \\
\text { Teacher: } \\
\text { expecting } \\
\text { retention } \\
\text { from } \\
\text { NT/NM }\end{array}$ \\
\hline $\begin{array}{l}\text { Suggested } \\
\text { change }\end{array}$ & $\begin{array}{l}\text { NOTES } \\
\text { TAKING }\end{array}$ & $\begin{array}{l}\text { NOTES } \\
\text { MAKING }\end{array}$ & $\begin{array}{l}\text { NOTES } \\
\text { REVIEWI } \\
\text { NG }\end{array}$ \\
\hline $\begin{array}{l}\text { Who/what } \\
\text { suggested } \\
\text { change }\end{array}$ & $\begin{array}{l}\text { Feedback } \\
\text { from POT } \\
\text { (Colleague as } \\
\text { critique- } \\
\text { friend); } \\
\text { Feedback } \\
\text { from students }\end{array}$ & $\begin{array}{l}\text { Feedback } \\
\text { from } \\
\text { students } \\
\text { during } \\
\text { survey }\end{array}$ & $\begin{array}{l}\text { Feedback } \\
\text { from Paper } \\
\text { Critique on } \\
\text { Action } \\
\text { Research } \\
\text { published } \\
\text { in a journal } \\
\text { on Notes } \\
\text { Taking and } \\
\text { Retention. }\end{array}$ \\
\hline $\begin{array}{l}\text { Effect/imp } \\
\text { act }\end{array}$ & $\begin{array}{l}\text { Free Recall } \\
\text { was } \\
\text { improved, } \\
\text { trying to } \\
\text { manage NT } \\
\text { practice but } \\
\text { unable to } \\
\text { adopt to any } \\
\text { particular } \\
\text { method }\end{array}$ & \begin{tabular}{l}
\multicolumn{2}{l}{ Improved } \\
free recall, \\
comprehensi \\
on skill \\
show some \\
satisfactory \\
results, \\
adding \\
lecture \\
notes,
\end{tabular} & $\begin{array}{l}\text { Accuracy is } \\
\text { improving, } \\
\text { higher } \\
\text { order } \\
\text { cognitive } \\
\text { skills are } \\
\text { sharpening. }\end{array}$ \\
\hline
\end{tabular}

\begin{tabular}{|l|l|l|}
\hline & $\begin{array}{l}\text { referring to } \\
\text { other } \\
\text { resources in } \\
\text { addition to } \\
\text { classroom } \\
\text { lectures. }\end{array}$ \\
\hline
\end{tabular}

Reflective practice is essential for good teaching according to Day (1993) who considers nature of teaching, self-knowledge and growth of teachers as important facets of it. Setting goals of reflective practice are signs indicating changes and improvement in future. Action Research is basically a link among various cycles which indicate changes and improvement which can be well understood as what is existing situation, what is the change required, who the actors are suggesting the change and what is finally the impact of change. Table no. 2 shows these links from precycle to cycle 1 ; cycle 1 to cycle 2 ; cycle 2 to cycle 3 .

It is observed that Notes taking, Notes making and Notes reviewing are the major changes in action that impacted their retention with regards to appreciate result in recall capacity and satisfactory result in comprehension and accuracy capacity. At every cycle the existing situation was analyzed and the actions were suggested to bring about a change through the actors involved.

The table clearly reveals that AR proceeded as a cycle of joint planning, action, observation and reflection, where reflection phase paved a way for further cycle of planning, acting, observing, and reflecting in a link.

\section{DATA AND ANALYSIS}

The data collected was qualitative and quantitative both. Pie charts were used for analyzing the feedback information, bar charts were used to compare the outcomes of retention tests, figures/flow charts were created to organize the observations and line graph was used to show the comparative progression of information retention through all the cycles. I kept on checking whether the data was in favor or against the established theories. I continued observing/jotting notes on what I was learning through my AR. I used visual presentations in the form of mind maps and flow charts to link the ideas throughout the cycles and discussed these visual maps with my AR participants as well as my critical friends. It supported me to interpret my findings, draw conclusions and implicate them for future teaching.

Pre-Cycle: During the pre-cycle, class observations showed that only $10 \%$ students could retain and reply the questions asked during the lecture. Only 5/22 were writing notes and others preferred listening. Very few students came with their note taking tools and paid attention during the lecture. I went to the class room with the checklist and noted my observations and analyzed the same. 
I did not disclose that I was filling up a checklist for their facial, and body gestures to avoid their conscious behavior which could in a way impact/alter my study outcomes. I captured some photos during my lecture hours to witness the observations but later did not publish them on my participant's request. The students' observed behavior was enough to understand their unawareness, and ignorance towards NT activities at this stage.

After analyzing the survey data, I found that $100 \%$ agreed on importance of NT for improving their retention as well as their attention-span. The reasons mentioned for not taking notes included their inability to focus on lecture and note taking in parallel, lack of motivation along with language difficulty (ESL). Language difficulty is a big obstacle in NT, which is also covered by Ferris and Tagg (1996).

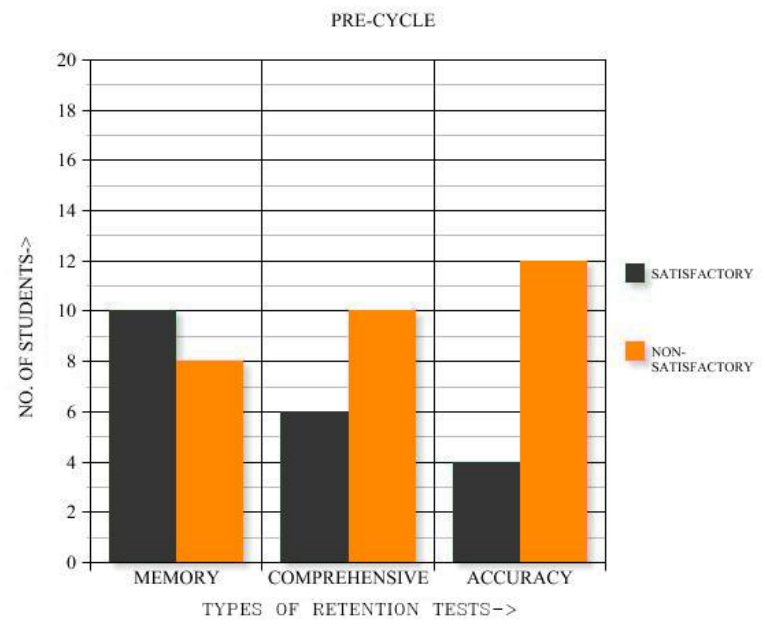

Figure 4. Retention test results from Pre-Cycle [source: author]

Test results showed that Free-recall (memory) was enhanced but only $40 \%$ relevant words were enlisted from the delivered information units. Out of total, $25 \%$ could answer satisfactorily in comprehension tests and others could not do so due to their inability to link ideas. $78 \%$ showed non satisfactory performance on accuracy test due to their low retention skills. During the Focus Group Discussion only $3 / 8$ admitted that they took regular notes, though all agreed that NT would help their retention levels. Majority mentioned that the reason for their inability to take notes was their lack of knowledge about correct note taking methods. The FGD was fully an actively participated conversation among the participants. I only had to initiate 3-4 key questions and the discussion went on with my unbiased role. There were no signs of disagreement among them on their study habits related to NT; they all commented on realizing the importance of NT to their retention but admitted for not practicing the same.
Irrespective of their academic GPAs, they showed unfamiliarity with proper NT techniques.

Cycle 1: NOTES TAKING- Class observations showed that $30 \%-40 \%$ students were ready to answer the questions during lecture session which was an improved number over the number during the pre-cycle. Almost $80 \%$ participants were taking notes during the lecture; though the method of NT used by them was of mixed type. When they were introduced with Cornell NT strategy, only $10 \%$ could do it successfully; others failed because of their lack of skills of organizing, categorizing and summarizing data (higher order cognitive skills). After introducing GraphicOrganizer as NT method, only $25 \%$ could do well while others struggled with the use of correct abbreviations, symbols and connections. During the survey feedback, majority replied that they were benefitted by NT for their retention, and the improvement was in terms of free recall of lectured information. Those who could not improve, the reason reported was their incapability of keeping pace with lecture speed during note taking. Test results revealed high satisfactory results for free recall type of questions [Ref fig5].

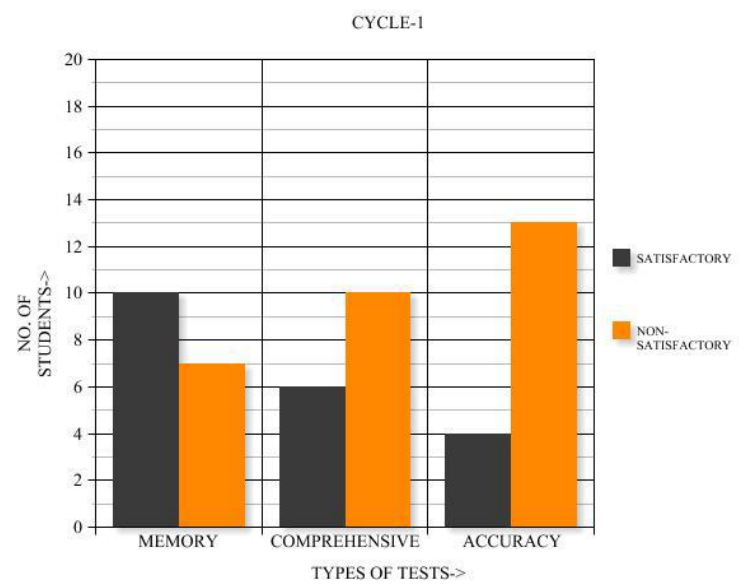

Figure 5. Retention tests results from Cycle-1 [source: author]

Cycle-2: NOTES MAKING- Students were seen 'making notes' by adding extra information from library books, internet sources etc. This was clearly observed in their samples of notes. Students' notes showed increase in the number of information units delivered during lectures with few higher order information units. The participants were using Arabic translation in required spaces to enhance their understanding and help them retain more. There was further increase in their class participation and lecture engagement. They preferred using graphical-organizers for NM. During survey, $90 \%$ students replied on choosing 'Notes Making' in addition to 'Notes Taking', with a justification that NM improved their retention by 25\%-50\% and helped for enhanced free recall. Test results showed 
some improvement in answering comprehension type of questions and high achievement in free recall [Ref fig 6].

CYCLE-2

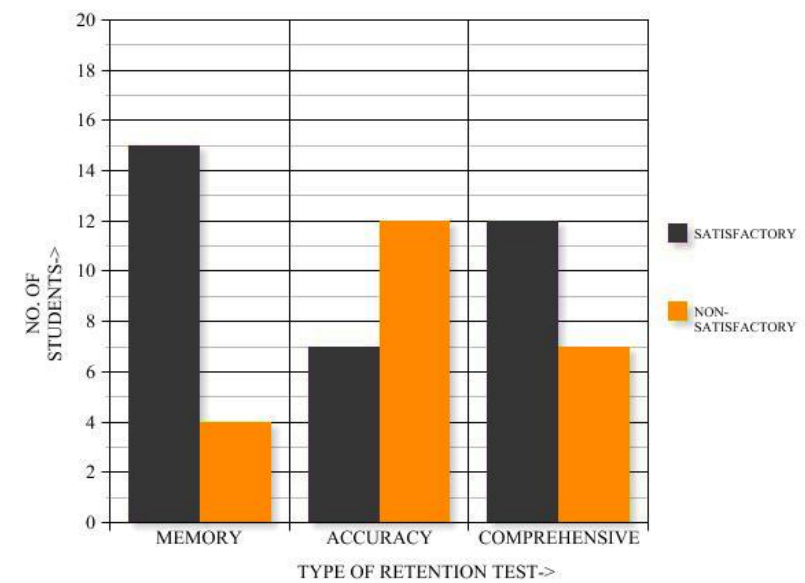

Figure 6. Retention tests results from Cycle-2 [source: author]

Cycle-3: NOTES REVIEWING- During cycle-3, participants were introduced with 'elaboration' as a method of notes reviewing. Almost every single participant contributed in random recall type discussion during lecture. Survey results showed that, all of them agreed that NT, NM and NR helped them in retaining lecture information but said to have different levels of impact on retention. $90 \%$ preferred NR over NT and NM because according to them it increased their retention by $50 \%$ and approximately $60 \%$ admitted that reviewing notes helped them to improve their skills of answering accurate type of questions. Retention test results showed satisfactory results under all types of retention-tests. Accuracy-skills have improved and now noted information units were more relevant to delivered units as compared to the previous cycle. [Ref fig 7].

\section{CYCLE-3}

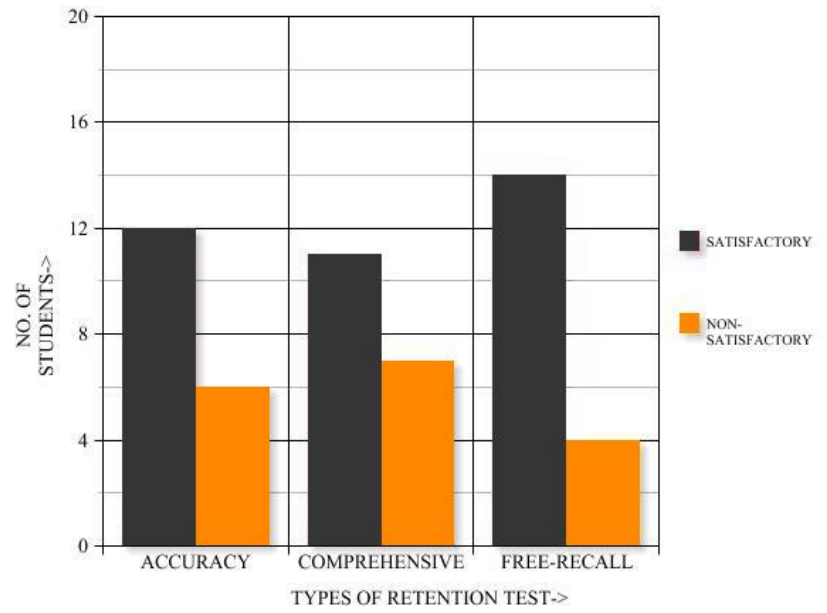

Figure 7. Retention tests results from cycle-3 [source: author]
During Focus Group Discussion, students mentioned that they generally use re-writing, re-reading, repeating etc. as methods for reviewing notes. All agreed on using NT, NM and NR for effective learning. They were completely against the fixed format / layout for NT and wanted the freedom to customize their own method. They all accepted that changes during AR have improved their retention, attention span and cognitive processing along with other benefits such as reduced exam fear, class distraction etc. Feedback survey results showed what participants preferred for their learning process but FGD helped to understand why they did so. I also maintained a record book for my reflective notes. During FGD, I found all the participants to be equally participative and irrespective of whether student was with high GPA or low GPA, they agreed on benefits of NT, NM, and NR. Using Mobile App (audio-recorder), to record the opinions of participants was very useful. My own reflective notes after FGD helped me to improve my own phases in AR. Feedback survey results showed what students preferred in learning process as priorities but FGD helped me in understanding their prioritization and preferences.

\section{LIMITATIONS/OBSTACLES IN ACTION RESEARCH}

Even after trying to control, the AR finding could not be free from independent variables that may have affected the results. These included lecture type, lecture topic, lecture length, lecture repeat, testing trials, question types: recognition and recall (Bruno et al, 2007) etc. Even individuality of students, individual working memory (WM) and learning style may have affected their knowledge retention (Hadwin et al, 2011). Some of the limitations faced during AR are shown in Table 3 and factors responsible for retention in Fig 8.

Table 3

Limitations/obstacles faced during AR

\begin{tabular}{|l|l|l|}
\hline $\begin{array}{l}\text { Independent } \\
\text { variable }\end{array}$ & Issues/limitations & Impact \\
\hline Time Period & $\begin{array}{l}\text { Insufficient, only 2 } \\
\text { weeks per cycle }\end{array}$ & $\begin{array}{l}\text { Results were } \\
\text { inadequate/poor to } \\
\text { meet the desired } \\
\text { theoretical } \\
\text { findings }\end{array}$ \\
\hline $\begin{array}{l}\text { Attitude of the } \\
\text { participants }\end{array}$ & $\begin{array}{l}\text { Lack of sincere } \\
\text { participation, lack } \\
\text { of intrinsic } \\
\text { motivation }\end{array}$ & $\begin{array}{l}\text { Half-hearted } \\
\text { participation in } \\
\text { some areas }\end{array}$ \\
\hline $\begin{array}{l}\text { Instructor- } \\
\text { related }\end{array}$ & $\begin{array}{l}\text { Assessment- for } \\
\text { Threshold risfactory } \\
\text { performance was } \\
\text { subjective, not based }\end{array}$ & $\begin{array}{l}\text { Test interpreted in } \\
\text { received could not } \\
\text { be inthentic way } \\
\text { an auth }\end{array}$ \\
\hline
\end{tabular}




\begin{tabular}{|l|l|l|}
\hline & $\begin{array}{l}\text { on earlier research, } \\
\text { less time was given } \\
\text { on assessing the } \\
\text { quality of notes. }\end{array}$ & \\
\hline Study-related & $\begin{array}{l}\text { Retention period: } \\
\text { no thought was } \\
\text { considered for the } \\
\text { appropriate retention } \\
\text { period/interval }\end{array}$ & $\begin{array}{l}\text { May have affected } \\
\text { the retention test } \\
\text { results }\end{array}$ \\
\cline { 2 - 3 } & $\begin{array}{l}\text { Training in note- } \\
\text { taking- no formal } \\
\text { training was given to } \\
\text { the participants }\end{array}$ & $\begin{array}{l}\text { Learners were } \\
\text { unable to take } \\
\text { notes in an } \\
\text { appropriate way. }\end{array}$ \\
\hline $\begin{array}{l}\text { Study habits: these } \\
\text { were not kept as } \\
\text { controlled variable }\end{array}$ & $\begin{array}{l}\text { Students study } \\
\text { habits affected the } \\
\text { results }\end{array}$ \\
\hline
\end{tabular}

The factors that can affect student learning may include- student variables, class room variables, teacher variables, school variable, parent variable, community variable etc. (Pine, n.d., p. 244-246). Table 3 discusses the factors as limitations during the study with respect to time period, which was 2 weeks per cycle approximately. It could be a short term span from observation point of view, longer period may have resulted differently. Level of Students' / Participants' attitude with respect to their devotion and motivation in participation during AR may have impacted the study results. I as Instructor, decided my own threshold for satisfactory result from retention tests and did not benchmark these against any earlier studies. This may be a factor which could have impacted my results. I did not give any formal training to the students in Notetaking. Also I did not make my participants to follow particular study habits. These could have surely added to the result outcomes. The AR was intended towards short term retention measurements but a precise definition of short term was not set based on any theoretical support.

FACTORS AFFECTING RETENTION OF INFORMATION

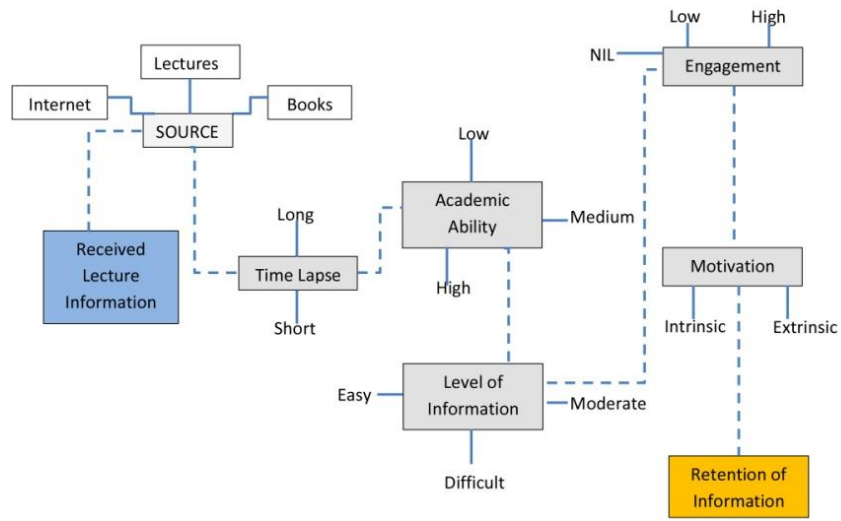

Figure 8. Factors affecting retention of information [source: author]
In addition to the table 3, Fig 8 above shows the various factors that may affect the retention of information in general and might have influenced my experiment as well. To start with is the source of receiving information that majorly includes the lecture along with other secondary sources like books, internet search engines etc. Lecture is a well prepared oral presentation on a topic by a qualitative person (Morgan, 2000). Students during the lecture are using their multiple senses and logical processing of information delivered to retain it. Retention of information is also related to time factor based on 2 issues: Duration and capacity as mentioned by Cowan (2009). Accordingly, duration means how long it will take to delay information units from memory. The process of receiving information starts with the sources of it, along and capacity means limit in how many information units can be held in storage. Academic ability of students whether he/she is having high GPA/low GPA can also be considered as a responsible factor to certain extent. Level of information from easy to difficult also has an effect on retention in short term memory. Another factor responsible is engagement with information affecting retention because complexity of information is a direct impacting factor. Finally to retain information, one needs to be motivated either via outside actors (extrinsic) or by oneself (Intrinsic). Because motivation is related to deep learning and deep learning is associated with information processing and retaining. 5 key factors that impact students' motivation are: teacher, student, content, method/process and environment (Williams and Williams, 2011).

\section{CONCLUSION}

1. 'No-notes-Taking' showed unsatisfactory achievement in recall, comprehension and accuracy type of questions. Research by Di Vesta and Grey (1972) favors this outcome but Aiken et al study (1975) objects as it didn't find any significant difference between participants who took notes and those who did not.

2. 'Notes-Taking' showed a high rate of free recall of information units. There is strong evidence from research that NT improves higher recall and performs better on far transfer task (Paper and Mayer, 1978); my AR showed high recall after NT, but no impact on far transfer task.

3. 'Notes-Making' helped in improving skills of the learners in dealing with comprehension type of questions, though there is no earlier study directly supporting this. I do not agree with Eisner and Rhode study (1959), which mentions that notes taking during lecture can distract the learners. But also feel that in addition to lecture notes if students refer different information resources like internet, library etc. their notes can be better in quality and understanding. It was evident from cycle-2 results which showed that the quality and quantity of notes was improved 
when students fixed their notes in their own time after the lecture. Students' feedback emphasized NM over NT and this can also be supported by Race (2010).

4. 'Notes-Reviewing' aided the accuracy skills of learners. This can be supported by Carter and Van Matre study (1975) which mentions that benefit of NT appears to be derived from the review rather than from the act of NT itself. Kiewra (1987) also support the same opinion. Middendorf and Macan (2002) mention that the act of NT also improves recall of applicant facts, while the act of NR improves judgment accuracy.

5. During all cycles of NT, NM and NR retention showed significant improvement.

6. During all cycles of NT, NM and NR students showed increased attention span, confidence and active participation from learners in a pyramidal manner (Ref fig 9).

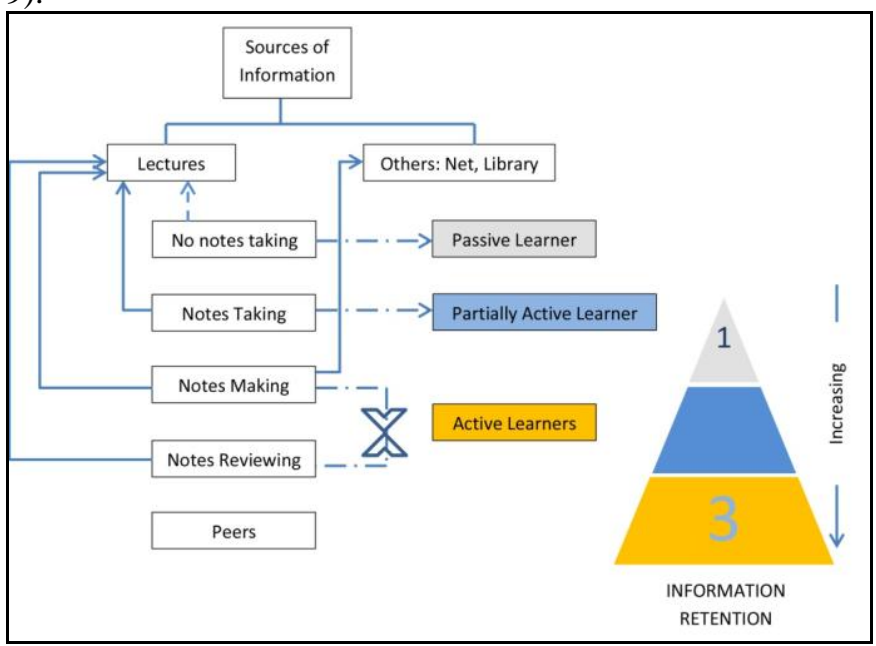

Figure 9. Strategies of retaining lectured-information and impact on learning type [source: author]

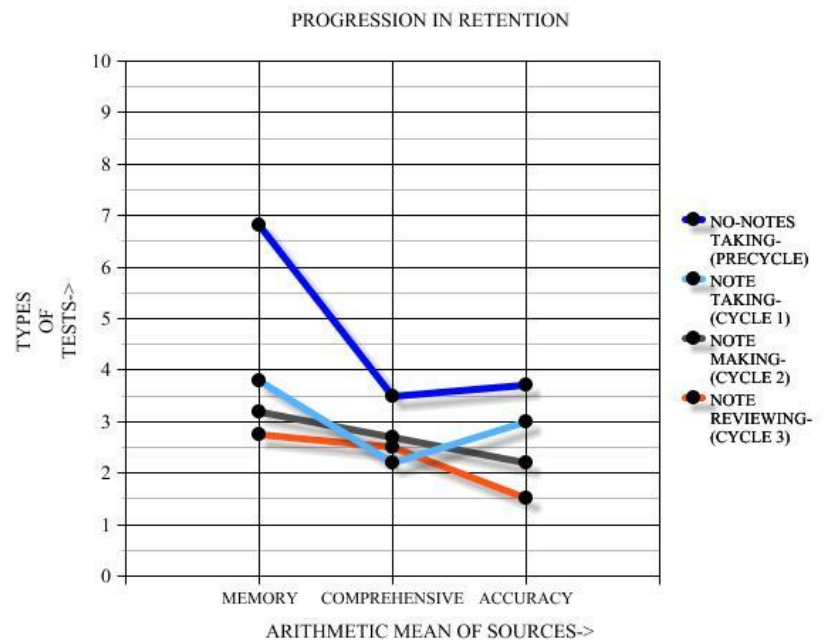

Figure 10. Progression in retention through all cycles [source: author]
The research helped me to gain lessons regarding note taking training and strategy. To improve NT, training can be implemented (Robin et Al. study, 1977) as it can help in increased noting of critical lecture points. It is also supported by studies of Rahmani and Sadeghi (2011) as well as Akintunde (2015).Training program trains the students to use their meta-cognitive skills where they learn to manage their learning by themselves (Biggs and Tang, 2010). Study by Paper and Mayer (1986), indicate that background information about lecture topic influences NT and performance; Pressley et. al. (1989) opposes this by saying it hampers generative process. My study observed a positive effect when I started sending lists of topic related important words in advance of lecture on NT and retention level.

I have read some studies that support and others that contradict the advantages of Cornell NT strategy. Hayati and Jalilifar (2009); Davoudi et.al. (2015) and Akintunde (2009) in favor of Cornell type, and Quintus et.al. (2012) mentioned a comment that it does not make a significant difference. Although not directly supported by abundance of empirical research, Cornell format employs several principles supported by Cognitive-Psychology and if followed properly can help them to construct new knowledge. My students during AR found it difficult because it involved multiple cognitive processing which discouraged them from using it. Structure of notes is an important factor in deciding the benefit of it (Mayer,1984; Kiewra et al.,1989)but giving freedom to the students to customize their own-NT-system is more helpful because it holds personal meaning for them (Ahn et al, 2016) and enables them to recall a high proportion of ideas recorded in a personal way (Kiewra,1987). Students shared a similar opinion during the feedback.

Reviewing notes is transforming notes into interactive mode and affects positively on retention and higher achievement of performance as was observed in 24/32 studies mentioned by Kiewra et al. (1995). Although importance of review process is well established, existing research has unfortunately offered only few suggestions on how students should actually review their notes.

Through my study, I realized that teachers can help increase students note taking by modifying their lecturing speed, quality and quantity of information units, giving cues and clues during lecture, lecture repeat etc. (Kiewra,1987).Carter and Van Matre (1975) study has emphasized on highly organized lectures. It is understood that students should focus on quality of notes and instructors should assess these notes using a systematic approach suggested by Chen (n.d.) (Ref fig 11). 


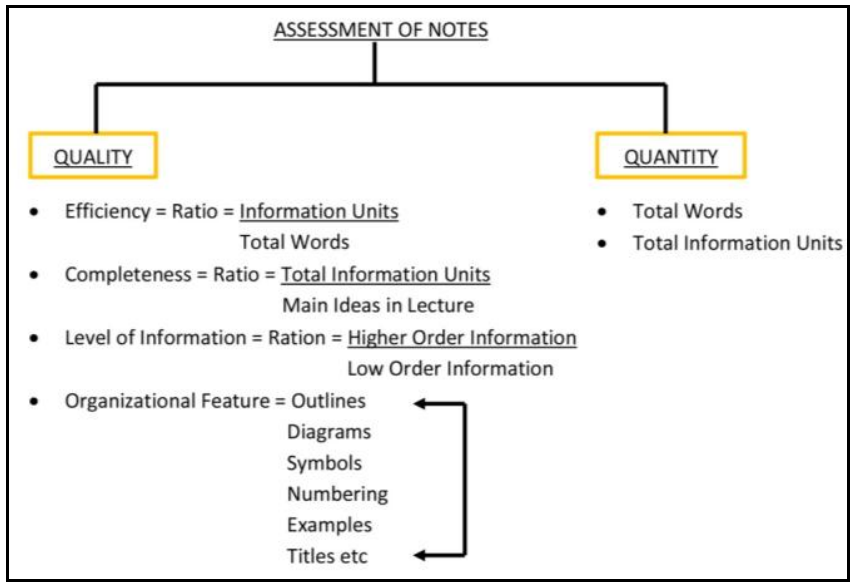

Figure 11. Notes assessment format [source: author] Note: figure 11 is based on the article by hen,n.d.

Recommendation for Future Cycle: After the reflections in and on research, I recommend a future cycle with a change of element as practicing 'Communal Note Taking'. It has been experimented by Ahn et al. (2016) with the understanding that students should be allowed to write information in the way they will remember; but as a member of community where learning through Notes taking does not take place in isolation. According to him, they should be encouraged to interact with peers, present what they have and be able to teach each-other what they have learned. This may enhance their retention on Dale's cone to 90\% (Anderson, n.d).

The research also helped me to gain an insight into a revival of interest in Self-Regulated Learning (SRL). Zimmerman (1998), mentions about positive relationship between SRL and academic achievement whereas Boekarts (1997) writes about lifelong learning as a result of SRL. Note taking allows students to develop the ability to ignore irrelevant information and seek-reorganize-elaborate and re-conceptualize acquired information in ways that increase understanding to connect information, create meanings and apply in new situation. Teachers can allow this to happen by asking students to practice notes interacting. A time has come to favor student-centered paradigm and stop treating our students as passive receptacles which can be filled with teachers' information.

I would like to conclude by commenting that success of Teaching Profession in HE, lies in continually growing and learning and $\mathrm{AR}$ has given me a way to achieve this through my own experience (Rust \&Clarke, n.d.). I have learned much more than just the answer to my research question and have rediscovered my desire to teach and improve teaching for betterment of teaching learning environment.

\section{Abbreviations Used}

HE- Higher Education; AR-Action Research; NT-Notes Taking; NM:-Notes Making; NR- Notes Reviewing; FGDFocus Group Discussion; FB- Feed back

\section{REFERENCES}

[1] Ahn. R., Ingham, S., Mendez, T., \& Pomona, C. (2016). Socially constructed learning activity: Communal notetaking as a generative Tool to promote Active Student Engagement. Transformative Dialogues: Teaching and Learning Journal, 8(3), 1-15.

[2] Akintunde, O. (2013). Effects of cornell, verbatim and outline note-Taking strategies on students' retrieval of lecture information in Nigeria. Journal of Education and Practice, 4(25), 67-73.

[3] Anderson, H.M. (2018). Dale's cone of experience. Available at:

http://www.queensu.ca/teachingandlearning/modules/active /documents/Dales_Cone_of_Experience_summary.pdf.

[4] Anderson, T.H. \& Armbuster, B.B. (1986). The value of taking notes during lectures. Available at: https://www.ideals.illinois.edu/bitstream/handle/2142/1757 4/ctrstreadtechrepv01986i00374_opt.pdf?sequence $=1$.

[5] Anon. (2016). Ebbinghaus and the forgetting curve. Available at: http://www.wranx.com/ebbinghaus-and-theforgetting-curve/.

[6] Anon. (2018). Outlining method for note taking. Available at:

https://www.missouristate.edu/assets/busadv2014/p.24.pdf. [7] Biggs, J. \& Tang, C. (2011). Teaching for quality learning at University. Berkshire, England: Open University Press.

[8] Boch, F. \& Piolat, A. (2005). Note taking and learning: A Summary of research. The WAC Journal, 16, 101-113.

[9] Boekaerts, M. (1999). Self-regulated learning: Where we are today?. International Journal of Educational Research, 31, 445-457.

[10] Boye, A. (2012). Note-taking in the $21^{\text {st }}$ century: Tips for instructors and students. Available at: https://www.depts.ttu.edu/tlpdc/Resources/Teaching_resour ces/TLPDC_teaching_resources/Documents/NotetakingWh itepaper.pdf.

[11] Bridge, D.J. (2005). Memory \& cognition: What difference does gender make? Available at: http://surface.syr.edu/cgi/viewcontent.cgi?article=1637\&co ntext=honors_capstone.

[12] Bruno, P., Sabrina D., Renaudineau, S., Poirie, R., \&, Savehe, E. (2009). Formation and stability of recognition memory: what happens upon recall?. Frontiers in Behavioral Neuroscience, 4, 1-11.

[13] Carter, J. F. \& Van Matre, N. H. (1975). Note taking versus note having. Journal of Educational Psychology, 67, 900-904. 
[14] Chen, C.R. (2013). Assessing Note-Taking. Available at:

http://fllcccu.ccu.edu.tw/conference/2005conference_2/dow nload/C13.pdf.

[15] Crawford, M.J., Ducker, N., MacGregor, L., Kojima, S., \& Siegel, J. (2015). Perspectives on Note taking in EFL Listening. Available at: https://jaltpublications.org/files/pdf-article/jalt2015-pcp_037.pdf.

[16] Davoudi, M., Sabzevari, Moattarian, N., \& Zareian, G. (2015). Impact of Cornell Note-Taking Method Instruction on Grammar Learning of Iranian EFL Learners. Journal of Studies in Education, 5(2), 252-265.

[17] Dezure, D., Kaplan, M., \& Deerman, M. (2001). Research on students note taking: Implications for faculty and graduate student instructors. Available at: https://www.researchgate.net/publication/247399328.

[18] Di Vesta, F. J., \& Gray, G. S. (1973). Listening and note taking: Immediate and delayed recall as functions of variations in thematic continuity, note taking, and length of listening-review intervals. Journal of Educational Psychology, 64, 278-287.

[19] DuBois, K.A., Christian, N.F., Mc Shane, A. D., Meyerhoffer, M., \& Roskelley, D. (1991). Note-taking functions and techniques. Journal of Educational Psychology, 83, 240-245.

[20] Dunkel, P. (1988). Academic listening and lecture note-taking for L1/L2 students: The need to investigate the utility of the axioms of good note taking. The Canada Journal, 6(1), 11-26.

[21] Ferris, D. \& Tagg, T. (1996). Academic listening /speaking tasks for ESL students: Problems, suggestions and implication. TESOL Quarterly, 30(2), 297-320.

[22] Fisher, J. L. \& Harris, M. B. (1974). Note taking and recall. The Journal of Educational Research, 67, 291-292.

[23] Flom, P. (2017). Validity \& reliability of focus groups. Available at:

http://www.ehow.com/facts_6778649_validity-reliabilityfocus-groups.html.

[24] Friedman, M. (2017). Notes on note-taking: Review of research and insights for students and instructors. Available at:

http://hilt.harvard.edu/files/hilt/files/notetaking_0.pdf.

[25] Guest Post. (2013). Note making: Brain exercise to enhance reading comprehension skills. Available at: http://knowledgeworks.org/worldoflearning/2013/01/notemaking-brain-exercise-to-enhance-reading-comprehensionskills-2/.

[26] Green, J. \& Thorogood, N. (2004). Qualitative methods for health research. London, United Kingdom: Sage Publications.

[27] Hadwin, A. \& Oshige, M. (2011). Self-regulation, coregulation, and socially shared regulation: Exploring perspectives of social in self-regulated learning theory university of Victoria. Teachers College Record, 113(2), 240-264.

[28] Hayati, A.M. \& Jalilifar, A. (2009). The impact of note-taking strategies on listening comprehension of EFL learners. English Language Teaching, 2(1), 101-111.

[29] Hismanoglu, M. (2000). Language learning strategies in foreign language Learning and teaching. Available at: http://iteslj.org/Articles/Hismanoglu-Strategies.html.

[30] Kiewra, K. A. (1987). Note taking and review: The research and its implications. Journal of Instructional Science, 16, 233-249.

[31] Kiewra, K. (1988). Note taking and Review strategies: Theoretical orientations, empirical findings and Instructional practices. Research and Teaching in Developmental Education, 4(2), 5-17.

[32] Kiewra, K. A. (1989). A review of note-taking: The encoding-storage paradigm and beyond. Educational Psychology Review, 1(2), 147-172.

[33] Kiewra, K. A., Benton, S.L., Kim, S., Risch, N., \& Christensen, M. (1995). Effects of note taking format and study technique on recall and relational performance. Contemporary Educational Psychology, 20, 172-187.

[34] King, A. (1992).Comparison of self- questioning, summarizing, and Note taking - review as strategies for learning from Lectures. American Educational research Journal, 29(2), 303-323.

[35] Kobayashi, K. (2005). What limits the encoding effect of note-taking? A meta-analytic examination. Contemporary Educational Psychology, 30, 242-262.

[36] Maxwell, G.S. (2001). Teacher observation in student assessment. Available at:

https://www.qcaa.qld.edu.au/downloads/publications/resear ch_qscc_assess_report_4.pdf.

[37] Mayer, R.E. (1987). A review of note-taking: The encoding-storage paradigm and beyond. Educational Psychology Review, 1(2), 147-172. Available at: https://link.springer.com/article/10.1007/BF01326640.

[38] Norton L.S. (1981). The effects of note-taking and subsequent use on long-term recall. Innovations in Education and Training Manual, 18(1), 16-22. Available at: http://srhe.tandfonline.com/doi/abs/10.1080/003303981018 0104.

[39] Palmer, D. (2007). What is the best way to motivate students in science? Teaching Science-The Journal of the Australian Science Teachers Association, 53(1), 38-42.

[40] Peper, R. J. \& Mayer, R. E. (1978). Note taking as a generative activity. Journal of Educational Psychology, 70, 514-522.

[41] Pine, G.J. (2017). Conducting teacher action research. in teacher action research: Building knowledge democracies. Available at: https://www.sagepub.com/sites/default/files/upmbinaries/27031_11.pdf. 
[42] Piolat, A., Olive, T., \& Kellogg, R. T. (2005). Cognitive effort during note taking. Applied Cognitive Psychology, 19, 291-312.

[43] Quintus, L., Borr, M., Duffield, S., Napoleon, L., \& Welch, A. (2012). The impact of the cornell note-taking method on students' Performance in a high school family and consumer sciences class. Journal of Family \& Consumer Sciences Education, 30(1), 27-38.

[44] Race, P. (2010). Making learning happen. ( $2^{\text {nd }}$ ed.). London, England : SAGE Publications Inc.

[45] Rahmani, M. \& Sadeghi, K. (2011). Effects of notetaking training on reading comprehension and recall. The Reading Matrix, 11(2), 116-128.

[46] Roediger, H. L. \& Karpicke, J. D. (2006). The power of testing memory: basic research and implications for educational practice. Perspectives on Psychological Science, 1(3), 181-210.

[47] Rust, F. \& Clarke, C. (2016). How to do action research in your classroom. Available at: https://www.naeyc.org/files/naeyc/Action_Research_Bookl et.pdf.

[48] Savin-Baden, M., \& Major, C. H. (2013). Qualitative research: The essential guide to theory and practice. Abingdon, United Kingdom: Routledge.
[49] Sheppard, A. (2015). Note taking strategies in a lecture environment. Available at: http://archives.algomau.ca/main/sites/default/files/2015035_003_013_001.pdf.

[50] Van der Meer, J. (2012). Students' note-taking challenges in the twenty-first century: Considerations for teachers and academic staff developers. Teaching in Higher Education, 17, 13-23.

[51] VanderStoep, S.W. \& Pintrich, P.R. (2008). Taking notes. Learning to learn: The skill and will of college success. Upper Saddle River, NJ: Prentice Hall.

[52] Williams, K. \& Williams, C. (2011). Five key ingredients for improving motivation. Research in Higher Education Journal, 11. Available at: http://aabri.com/manuscripts/11834.pdf.

[53] Yeasmin, S. \& Rahman, K.F. (2012).'Triangulation' research method as the tool of social science research. $B U P$ Journal, 1(1), 154-163.

[54] Zimmermann, B.J. (2002). Becoming a self-regulated Learner: An over review. Theory into Practice, 41(2), 6470 . 